\title{
Reduced Peripheral Conversion of Thyroxine to Triiodothyronine in Patients with Hepatic Cirrhosis
}

\author{
Setsuo Nomura, Constance S. Pittman, Joseph B. Chambers, Jr., \\ Melvin W. Buck, and Taeko ShImIzU \\ From the Endocrine Research Laboratory, Veterans Administration Hospital \\ and the Department of Medicine, University of Alabama School of Medicine, \\ Birmingham, Alabama 35233
}

A B S T R A C T The role of liver in the peripheral conversion of thyroxine $\left(T_{4}\right)$ to triiodothyronine $\left(T_{3}\right)$ was studied in normal subjects and patients with alcoholic liver disease by measurement of thyrotrophin ( $\mathrm{TSH}$ ) and total and free $\mathrm{T}_{4}$ and $\mathrm{T}_{3}$ in random and serial serum samples. Also, $T_{4}$ to $T_{3}$ conversion rates and $T_{3}$ disposal rates were compared by noncompartmental analysis. While the mean total serum $T_{4}$ values were similar for the two groups, 8.6 and $8.1 \mu \mathrm{g} / \mathrm{dl}$, the mean free $T_{4}$ value was significantly higher in the cirrhotic patients $(3.3 \mathrm{ng} / \mathrm{dl})$ than in the normal subjects (2.1 ng/dl, $P<0.001$ ). The mean serum $\mathrm{T}_{\mathbf{s}}$ value, 85 $\mathrm{ng} / \mathrm{dl}$, was significantly reduced in the hepatic patients as compared to a mean serum $\mathrm{T}_{8}$ value of $126 \mathrm{ng} / \mathrm{dl}$ in the normal subjects $(P<0.001)$, while the free $\mathrm{T}_{3}$ value was $0.28 \mathrm{ng} / \mathrm{dl}$ in both groups. The reduction of the serum total and free $T_{3}$ values were closely correlated with the degree of liver damage, as indicated by elevation of serum bilirubin $(r=-0.547)$ and reduction of serum albumin $(r=0.471)$. The mean serum TSH level was $3.1 \mu \mathrm{U} / \mathrm{ml}$ in the normals and $7.1 \mu \mathrm{U} /$ $\mathrm{ml}$ in the cirrhotic patients $(P<0.001) .15 \%$ of the hepatic patients had serum TSH values above $10 \mu \mathrm{U} /$ $\mathrm{ml}$, which, however, did not correlate with any of the four liver function tests studied. Serial blood sampling from two convalescing patients with alcoholic hepatitis showed a gradual normalization of serum TSH and $\mathrm{T}_{3}$ levels as the liver function improved. After oral $T_{4}$ administration, $0.25 \mathrm{mg} /$ day for 10 days, three of four cirrhotic patients studied failed to raise their serum $T_{3}$ values. The mean $T_{4}$ to $T_{3}$ conversion rate of seven normal subjects was $35.7 \%$. The mean $\mathrm{T}_{4}$ to $\mathrm{T}_{3}$ conversion rate of four cirrhotic patients studied was significantly reduced to $15.6 \%(P<0.001)$. The mean

Receized for publication 12 March 1974 and in revised form 22 May 1975. disposal rates of $T_{4}$ and $T_{3}$ of the normal subjects were 114 and $34 \mu \mathrm{g} /$ day, respectively. The ratio of $T_{\text {. dis- }}$ posal to $T_{3}$ disposal was 3.5 . In contrast, the mean $T_{4}$ disposal rate, $82 \mu \mathrm{g} /$ day, and the mean $\mathrm{T}_{3}$ disposal rate, $10 \mu \mathrm{g} /$ day, were both reduced in the cirrhotic patients. Their ratio of $T_{4}$ disposal to $T_{3}$ disposal was 7.9. These findings suggest that impairment of $T_{4}$ conversion in patients with advanced hepatic cirrhosis may lead to reduced $T_{3}$ production and lowered serum $T_{3}$ level. Therefore, the liver is one of the major sites of $T_{\text {. }}$ conversion to $\mathrm{T}_{\mathbf{3}}$.

\section{INTRODUCTION}

It is now well established that thyroxine $\left(T_{4}\right)^{1}$ is converted to triiodothyronine $\left(\mathrm{T}_{3}\right)$ in the peripheral tissues of man (1-4), rat (5), and sheep (6). The contribution of this pathway to the total $T_{3}$ production appears to be higher in man and sheep than in rat. $T_{8}$ can also be converted from $T_{4}$ in vitro by perfused rabbit liver (7) and rat heart (8), by slices of pituitary (9), kidney (10), and brain (11), and by tissue cultures of human fibroblast (12), kidney, and liver (13). Still, it is not known in what proportion the different organs contribute to the overall $T_{3}$ production in the intact animal under physiological circumstances. Several early studies suggest that liver plays a role in the metabolism of thyroid hormones (13-20). Cavalieri and Searle (17) estimated the hepatic volume of distribution for $T_{4}$ to be approximately $38 \%$ of the total $\mathrm{T}_{4}$ volume of distribution. More recently, another laboratory as well as our own reported the observation of reduced $T_{s}$ and elevated thyrotropin (TSH) levels in the serum of

1 Abbreviations used in this paper: MCR, metabolic clearance rate; $\mathrm{T}_{3}$, triiodothyronine; $\mathrm{T}_{4}$, thyroxine; $\mathrm{TSH}$, thyrotropin. 

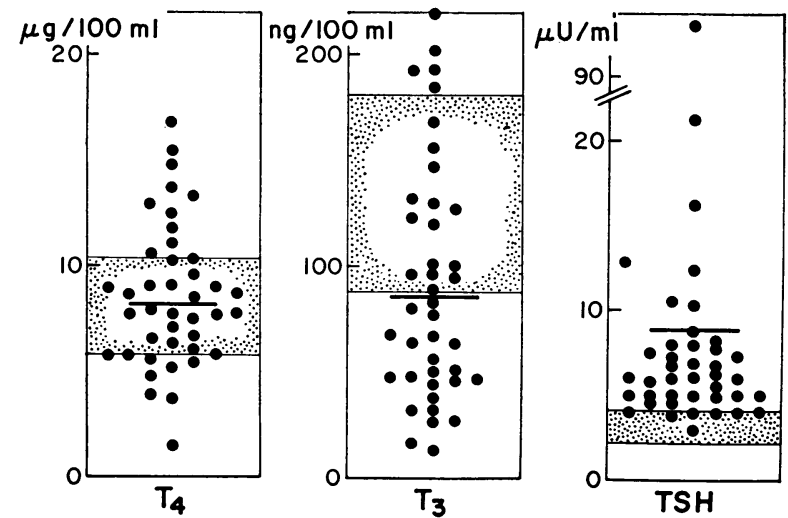

Figure 1 Random serum $T_{4}, T_{8}$, and TSH were assayed by radioimmunoassay in normal subjects and hepatic patients. The range of values obtained from normal subjects is shown as shaded area. The individual values from the liver patients are shown as dots while the group mean is shown as a horizontal bar.

hepatic patients $(21,22)$ that suggested possible failure of $T_{4}$ conversion. The present study was carried out to define the role of liver in the peripheral conversion of $T_{4}$ to $T_{3}$. Random and serial serum samples from normal subjects and hepatic patients were assayed for $\mathrm{TSH}$, and total and free $\mathrm{T}_{4}$ and $\mathrm{T}_{3}$. The $\mathrm{T}_{4}$ to $\mathrm{T}_{3}$ conversion rate and the $T_{4}$ and $T_{s}$ disposal rates were estimated in both normal subjects and cirrhotic patients by noncompartmental analysis and were found to be markedly reduced in the cirrhotic patients. The results of these studies constitute the substance of the following report.

\section{METHODS}

Subjects. Normal volunteers were selected from the medical personnel for their good general health and absence of any thyroid or liver disorder. The hepatic patients were chosen from the hospitalized patients of two urban hospitals for advanced alcoholic liver disease, as documented by different combinations of hepatomegaly, icterus, ascites, abnormal serum proteins, and elevated bilirubin, alkaline phosphatase, and transaminase levels. The serum bilirubin, transaminase, and alkaline phosphatase were measured by AutoAnalyzer (Technicon Instruments Corporation, Ardsley, N. Y.) and the serum albumin was measured by electrophoresis in the hospital laboratories. Among the etiologies of the liver disorder were alcoholic cirrhosis, alcoholic hepatitis, and acute viral hepatitis. All subjects had given their informed consent for the present study.

Hormone assays. Serum TSH (23), $\mathrm{T}_{4}$ (24), and $\mathrm{T}_{8}$ (25) were assayed by the double-antibody technique of radioimmunoassay. Serum free $T_{4}$ and free $T_{3}$ were measured by dialysis, simultaneously, according to the method of Sterling and Brenner (26) with minor modifications. Human pituitary TSH standard $68 / 38$ was a gift from the National Institute for Medical Research (Mill Hill, London). The purified human TSH for iodination was pro- vided by the National Institute of Arthritis, Metabolism and Digestive Diseases (Bethesda, Md.). The $T_{4}$ and $T_{2}$ standards were purchased from Sigma Chemical Co. (St. Louis, Mo.). The anti- $T_{4}$ antiserum and the anti- $T_{3}$ antiserum were raised in our laboratory in rabbits immunized with bovine albumin conjugate of $T_{4}$ or $T_{8}$. The final dilution of anti- $\mathrm{T}_{4}$ antiserum was $1: 2,500$ and that of anti- $\mathrm{T}_{\mathrm{s}}$ antiserum was $1: 12,000$. An anti-rabbit gammaglobulin antiserum from goat was used as the second antibody and was purchased from Antibodies, Inc. (Davis, Calif.). The interassay coefficients of variation for $T S H, T_{4}$, and $T_{3}$ assays were $7.9,3.4$, and $7.9 \%$, respectively. The intraassay coefficients of variation was $2.2 \%$ for $\mathrm{TSH}, 4.1 \%$ for $\mathrm{T}_{4}$, and $3.9 \%$ for $\mathrm{T}_{8}$. Each sample was run in triplicate. The random serum samples from normal subjects and hepatic patients were randomized and assayed together. In the longitudinal studies all sera from the same subject were assayed together. The least detectable concentration in the TSH assay varied between 1.5 to 2.1 $\mu \mathrm{U} / \mathrm{ml}$, calculated as the mean minus two standard deviations of the zero tube. Subjects with undetectable TSH level were routinely assigned a level half the respective least detectable concentration for the calculation of means. For the present study, no normal control had an undetectable TSH level.

Kinetic analysis. Radiothyroxine labeled with ${ }^{125} \mathrm{I}$ and radiotriiodothyronine labeled with ${ }^{181} \mathrm{I}$, with a specific activity over $40 \mu \mathrm{Ci} / \mu \mathrm{g}$ and $50 \mu \mathrm{Ci} / \mu \mathrm{g}$, respectively, were purchased from Amersham-Searle Corp. (Arlington Heights, IIl.). The purity of the radioactive hormones was $95-97 \%$, as monitored by paper chromatography. They were diluted to the desired concentration with a $1 \%$ human albumin solution in normal saline and then passed through a Millipore filter (Swinnex $0.22 \mu \mathrm{m}$, Millipore Corp., Bedford, Mass.). The radioisotopes were assayed simultaneously in a well scintillation counter with a two-channel analyzer. The assay of ${ }^{125} \mathrm{I}$ activity was corrected for ${ }^{121} \mathrm{I}$ spillage.

The subjects were given $T_{4}$ by mouth, $0.25 \mathrm{mg}$ daily, starting at least 2 wk before and 5 drops three times a day of Lugol's solution, starting just before study. At the start of study, the patients were given an intravenous injection of a combined dose of $60 \mu \mathrm{Ci}$ of ${ }^{125} \mathrm{I}$-labeled $\mathrm{T}_{4}$ and $100 \mu \mathrm{Ci}$ of ${ }^{181}$ I-labeled $\mathrm{T}_{3}$ in $1 \%$ sterile human albumin solution. Blood samples were taken at $0,0.15,1$, and $2 \mathrm{~h}$ and then at 4-h intervals during the first $48 \mathrm{~h}$ and then at daily intervals up to 14 days. The serum was separated and an aliquot was stored at $-20^{\circ} \mathrm{C}$ for radioimmunoassays later. The remaining aliquot was treated with propylthiouracil and sodium iodide, and precipitated with trichloroacetic acid as described elsewhere (3). The precipitate was extracted three times with three volumes of ethanol. The difference of radioactivity between the total precipitate and the extracted precipitate was assumed to represent the hormonal activity. The dose standard was added into the zero-time serum sample of each subject precipitated and extracted similarly. The recovery of radioactive $\mathrm{T}_{4}$ and $\mathrm{T}_{3}$ was $90 \%$ and $85 \%$, respectively.

Calculation. The serum radioactivity (percentage of dose per liter) was plotted as a function of time.

The metabolic clearance rate, $T_{4}$ and $T_{3}$ disposal rates, and the conversion rate of $T_{4}$ to $T_{3}$ were estimated by the noncompartmental method of Tait (27) with minor modifications (28). The metabolic clearance rate (MCR), expressed in liters per day, was calculated from the area under the curve of the hormonal radioactivity disappearance from serum according to Simpson's rule. 
TABLE I

Clinical Data of Consecutively Hospitalized Liver Patients



All patients were men.

* Deleted from calculation. 
TABLE II

The Serum Thyroid Hormones in Patients with Alcoholic Hepatitis and/or Cirrhosis

\begin{tabular}{|c|c|c|c|c|c|c|c|}
\hline \multirow[b]{2}{*}{ Patients } & \multicolumn{3}{|c|}{$T_{4}$} & \multicolumn{3}{|c|}{$\mathrm{T}_{3}$} & \multirow[b]{2}{*}{ TSH } \\
\hline & Total & Free fraction & Free & Total & Free fraction & Free & \\
\hline & $\mu g / d l$ & $\%$ & $n g / d l$ & $\mu g / d l$ & $\%$ & $n g / d l$ & $\mu U / m l$ \\
\hline $6^{*}$ & 1.5 & 0.027 & 0.4 & 13 & 0.285 & 0.04 & 93.1 \\
\hline 7 & 3.9 & 0.077 & 3.0 & 16 & 0.483 & 0.08 & 5.7 \\
\hline 8 & 3.7 & 0.075 & 2.8 & 27 & 0.490 & 0.13 & 6.3 \\
\hline 9 & 6.7 & 0.053 & 3.6 & 32 & 0.395 & 0.13 & 7.9 \\
\hline 10 & 8.5 & 0.053 & 4.5 & 31 & 0.443 & 0.14 & 4.9 \\
\hline 11 & 5.6 & 0.042 & 2.4 & 38 & 0.404 & 0.15 & 3.7 \\
\hline 12 & 5.4 & 0.049 & 2.6 & 44 & 0.390 & 0.17 & 16.4 \\
\hline 13 & 8.7 & 0.066 & 5.7 & 46 & 0.494 & 0.23 & 12.4 \\
\hline 14 & 5.4 & & & 46 & & & 12.4 \\
\hline 15 & 5.8 & 0.082 & 4.8 & 47 & 0.582 & 0.27 & 5.1 \\
\hline 16 & 5.7 & & & 47 & & & 4.1 \\
\hline 17 & 7.7 & 0.050 & 3.9 & 48 & 0.352 & 0.17 & 5.9 \\
\hline 18 & 6.3 & 0.085 & 5.4 & 50 & 0.600 & 0.30 & 3.0 \\
\hline 19 & 7.1 & 0.037 & 2.6 & 51 & 0.279 & 0.14 & 7.5 \\
\hline 20 & 7.9 & 0.045 & 3.6 & 56 & 0.344 & 0.19 & 8.8 \\
\hline 21 & 7.5 & 0.033 & 2.5 & 64 & 0.331 & 0.21 & 4.1 \\
\hline 22 & 8.9 & & & 64 & & & 4.0 \\
\hline 23 & 6.5 & 0.037 & 2.4 & 67 & 0.309 & 0.21 & 6.8 \\
\hline 24 & 6.0 & 0.069 & 4.1 & 68 & 0.496 & 0.34 & 5.0 \\
\hline 25 & 11.0 & 0.025 & 2.8 & 77 & 0.210 & 0.16 & 7.3 \\
\hline 26 & 8.6 & 0.041 & 3.5 & 80 & 0.351 & 0.28 & 10.4 \\
\hline 27 & 9.0 & 0.042 & 3.8 & 83 & 0.362 & 0.30 & 6.8 \\
\hline 28 & 7.7 & 0.031 & 2.4 & 89 & 0.270 & 0.24 & 6.0 \\
\hline 29 & 10.3 & 0.032 & 3.3 & 95 & 0.320 & 0.30 & 21.3 \\
\hline 30 & 4.7 & 0.032 & 1.5 & 96 & 0.311 & 0.30 & 4.4 \\
\hline 31 & 13.3 & 0.028 & 3.7 & 100 & 0.238 & 0.24 & 6.0 \\
\hline 32 & 5.7 & 0.034 & 1.9 & 101 & 0.303 & 0.31 & 4.0 \\
\hline 33 & 13.7 & 0.029 & 4.0 & 120 & 0.260 & 0.31 & 4.9 \\
\hline 34 & 9.6 & 0.048 & 4.6 & 123 & 0.390 & 0.48 & 10.2 \\
\hline 35 & 10.6 & 0.029 & 3.0 & 127 & 0.270 & 0.34 & 7.2 \\
\hline 36 & 9.1 & 0.027 & 2.5 & 132 & 0.297 & 0.39 & 7.9 \\
\hline 37 & 12.9 & 0.026 & 3.4 & 147 & 0.218 & 0.32 & 5.0 \\
\hline 38 & 7.8 & 0.030 & 2.3 & 156 & 0.270 & 0.42 & 5.6 \\
\hline 39 & 7.7 & 0.032 & 2.5 & 184 & 0.261 & 0.48 & 5.1 \\
\hline 40 & 9.0 & 0.034 & 3.1 & 193 & 0.286 & 0.55 & 7.7 \\
\hline 41 & 14.8 & 0.024 & 3.6 & 219 & 0.224 & 0.49 & 4.2 \\
\hline Patient mean & 8.1 & 0.044 & 3.3 & 85 & 0.351 & 0.27 & 7.1 \\
\hline$\pm \mathrm{SD}$ & 2.7 & 0.016 & 0.9 & 50 & 0.103 & 0.52 & 3.8 \\
\hline Control mean & 8.6 & 0.024 & 2.1 & 126 & 0.256 & 0.28 & 3.1 \\
\hline$\pm \mathrm{SD}$ & 1.7 & 0.001 & 0.3 & 23 & 0.028 & 0.02 & 0.6 \\
\hline$P$ & NS & $<0.001$ & $<0.001$ & $<0.001$ & $<0.005$ & NS & $<0.001$ \\
\hline
\end{tabular}

* Data deleted from calculation.

\section{RESULTS}

Random serum samples from 33 normal medical personnel and 45 hepatic patients were assayed for TSH and total and free $T_{4}$ and $T_{8}$. The age range of the normal subjects was $22-48 \mathrm{yr}$. They were free of any thyroid or liver disease by history and physical exam- ination. The hepatic patients were chosen from patients admitted consecutively to the medical wards with an admitting diagnosis of hepatitis or cirrhosis. All hepatic patients had hepatomegaly and many had icterus and ascites as well. Five of these patients had clinical features compatible with acute viral hepatitis while the 
remainder presented with acute alcoholic hepatitis and/or alcoholic cirrhosis. Alcohol intoxication was absent at the time of blood sampling. The results from these two groups are compared in Fig. 1 and the clinical information of the hepatic patients is tabulated in Table I. The data of two hepatic patients were deleted from the calculation of group means. One of these patients, P. W., No. 6, was considered to have primary hypothyroidism besides his liver disorder. The other patient, J. P., No. 4, had a history of Graves' disease for which he had received ${ }^{151} \mathrm{I}$ therapy $6 \mathrm{yr}$ before.

The recovery of unlabeled $T_{3}$ added to a pool of serum from patients with liver disease did not differ from the recovery data of a pool of normal serum, in agreement with the observation by Chopra, Solomon, Chopra, Young, and Chua Teco (21). Bilirubin added into the assay tubes up to $100 \mathrm{mg} / \mathrm{dl}$ did not shift the curve of TSH standard.

The studies of patients with alcoholic liver disease are shown in Table II. The mean levels of serum total and free $T_{4}$ of the normal subjects were $8.6 \pm 1.7$ $\mu \mathrm{g} / \mathrm{dl}$ and $2.1 \pm 0.3 \mathrm{ng} / \mathrm{dl}$, respectively. The mean levels of the total and free serum $T$, of the hepatic patients were $8.1 \pm 2.7 \mu \mathrm{g} / \mathrm{dl}$ and $3.3 \pm 0.9 \mathrm{ng} / \mathrm{dl}$, respectively. There was no difference between the mean total serum $T$. levels, while the mean free serum $T$, level of the hepatic patients was significantly higher than that of the normal subjects $(P<0.001)$.

The mean serum $T_{8}$ concentration of the normal controls was $126 \pm 23 \mathrm{ng} / \mathrm{dl}$. The mean serum $\mathrm{T}_{8}$ concentration of the hepatic patients was $85 \pm 50 \mathrm{ng} / \mathrm{dl}$. The difference between the $\mathrm{T}_{3}$ levels of these two groups was statistically significant $(P<0.001) .21$ of the patients had $T_{3}$ levels below the range of normal controls and many had $T_{s}$ values low enough to be compatible with advanced hypothyroidism. The serum free $T_{3}$ fraction was high, so the serum free $T_{s}$ was low in the patients with low serum total $T_{8}$ and high in the patients with normal levels of serum total $T_{s}$. The mean serum free $T_{8}$ level was the same for both groups $(0.27$ and $0.28 \mathrm{ng} / \mathrm{dl})$. The reduction of serum $\mathrm{T}_{3}$ in the hepatic patients was proportionately greater than the reduction of their serum $T_{4}$ values. The mean total $T_{4} /$ total $T_{8}$ ratio of the normal controls was 62 \pm 9 , whereas that of the liver patients was nearly doubled, $117 \pm 52(P<0.05)$. A similarly significant difference between the free $T_{t} /$ free $T_{s}$ ratios of the normal controls (7.5) and the hepatic patients (14.4) was observed. The reduction of serum total and free $T_{\mathbf{z}}$ levels was poorly correlated with the levels of serum transaminase or alkaline phosphatase (Table III). However, it showed a positive correlation with the serum albumin concentration $(r=0.471)$ and a negative correlation with the serum bilirubin concentration $(r=-0.547)$. Therefore, the alteration of serum $\mathrm{T}_{\mathbf{s}}$ level more closely reflected the synthetic capacity of the liver than its cellular integrity.

The mean serum TSH level of the normal subjects was $3.1 \pm 0.6 \mu \mathrm{U} / \mathrm{ml}$. The mean serum $\mathrm{TSH}$ of the hepatic patients was $7.1 \pm 3.8 \mu \mathrm{U} / \mathrm{ml}$. The difference between the TSH values of these two groups was statistically significant, with a $P$ value of $<0.001$. Six of these patients had TSH values above $10 \mu \mathrm{U} / \mathrm{ml}$, a level commonly used for the diagnosis of primary hypothyroidism. Sera were available for the measurement of serum free $T_{4}$ and $T_{8}$ in five of these six patients. All of them had high levels of serum free $T_{4}$. Only two of these patients showed reduced levels of serum free $T_{8}$, while the others had either high or normal levels of serum free $T_{3}$. None of these patients were clinically hypothyroid and none had findings of Hashimoto's thyroiditis. The levels of TSH could not be correlated with the levels of serum free $T_{4}(r=0.098)$, serum free $T_{3}(r=0.035)$, or the ratio of free $T_{4}$ to free $T_{3}$ $(r=0.024)$. Some of the patients who had marked re-

TABLE III

The Relationship between the Liver Function Tests and the Thyroid Function Tests Expressed by the Pearson's Correlation Coefficients

\begin{tabular}{|c|c|c|c|c|}
\hline & $\underset{\text { Silirubin }}{\text { Serum }}$ & $\begin{array}{c}\text { Serum } \\
\text { transaminase }\end{array}$ & $\begin{array}{c}\text { Serum } \\
\text { alkaline } \\
\text { phosphatase }\end{array}$ & $\begin{array}{c}\text { Serum } \\
\text { albumin }\end{array}$ \\
\hline Total $\mathrm{T}_{4}$ & $0.425^{*}$ & 0.014 & 0.044 & $0.352^{*}$ \\
\hline Total $\mathrm{T}_{3}$ & $0.547^{*}$ & 0.152 & 0.200 & $0.471^{*}$ \\
\hline Total $\mathrm{T}_{4} /$ total $\mathrm{T}_{3}$ & $0.622^{*}$ & 0.202 & 0.230 & $0.348^{*}$ \\
\hline Free $T_{4}$ & 0.144 & 0.166 & 0.003 & 0.125 \\
\hline Free $T_{3}$ & $0.531^{*}$ & 0.209 & 0.252 & $0.376^{*}$ \\
\hline Free $T_{4} /$ free $T_{3}$ & $0.696^{*}$ & 0.242 & 0.257 & $0.384^{*}$ \\
\hline TSH & 0.226 & 0.012 & 0.189 & 0.182 \\
\hline
\end{tabular}

${ }^{*} P<0.05$. 
TABLE IV

The Serum Thyroid Hormones in Patients with Acute Viral Hepatitis

\begin{tabular}{|c|c|c|c|c|c|c|c|}
\hline \multirow[b]{2}{*}{ Patients } & \multicolumn{3}{|c|}{ T. } & \multicolumn{3}{|c|}{$T_{3}$} & \multirow[b]{2}{*}{ TSH } \\
\hline & Total & Free fraction & Free & Total & Free fraction & Free & \\
\hline & $\mu g / d l$ & $\%$ & $n g / d l$ & $\mu g / d l$ & $\%$ & $n g / d l$ & $\mu U / m l$ \\
\hline 1 & 10.2 & 0.043 & 4.4 & 95 & 0.310 & 0.30 & 5.0 \\
\hline 2 & 12.5 & 0.029 & 3.6 & 130 & 0.225 & 0.29 & 6.8 \\
\hline 3 & 15.4 & 0.026 & 4.0 & 168 & 0.193 & 0.32 & 5.7 \\
\hline $4^{*}$ & 16.8 & & & 192 & & & 4.0 \\
\hline 5 & 7.4 & 0.021 & 1.6 & 202 & 0.187 & 0.38 & 4.6 \\
\hline Patient mean & 11.4 & 0.030 & 3.6 & 149 & 0.229 & 0.32 & 5.5 \\
\hline$\pm \mathrm{SD}$ & 3.4 & 0.009 & 0.8 & 46 & 0.057 & 0.04 & 1.0 \\
\hline Control mean & 8.6 & 0.024 & 2.1 & 126 & 0.256 & 0.28 & 3.1 \\
\hline$\pm \mathrm{SD}$ & 1.7 & 0.001 & 0.3 & 23 & 0.028 & 0.02 & 0.6 \\
\hline$P$ & $<0.01$ & $<0.050$ & $<0.001$ & NS & NS & $<0.025$ & $<0.001$ \\
\hline
\end{tabular}

* Data deleted from calculation.

duction of serum free $\mathrm{T}_{3}$ had serum TSH level below $10 \mu \mathrm{U} / \mathrm{ml}$. (Patients 7, 8, 9, 10, 11, 17, 19, 20, 25).

The number of patients with acute viral hepatitis included in this study was small. As compared to the

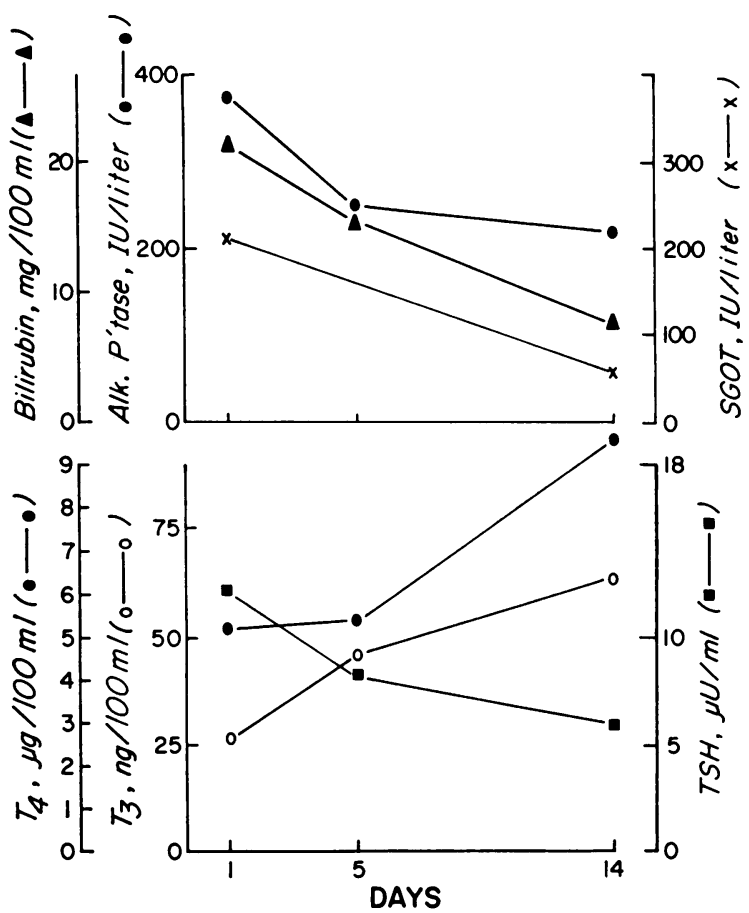

Figure 2 A 53-yr-old white man (W. W.), who presented with a history of chronic and acute alcohol abuse and acute alcoholic hepatitis. He had jaundice and hepatomegaly. His hepatic dysfunction improved on diet and bed rest. normal controls, they appeared to have higher values of serum total and free $T_{4}$ as well as higher values of serum TSH (Table IV). Their ratios of total $\mathrm{T}_{4}$ to total $T_{3}(88 \pm 21)$ and free $T_{4}$ to free $T_{3}(12 \pm 4)$ suggest that the patients with acute viral hepatitis also have lowered serum $T_{8}$ levels relative to the levels of serum $\mathrm{T}_{4}$.

A longitudinal study of liver function, serum TSH, $T_{4}$, and $T_{3}$ was carried out in two hepatic patients with moderately severe alcoholic hepatitis. The results of these patients were similar and one of these studies is depicted in Fig. 2. The results demonstrated that the alterations of serum $\mathrm{TSH}$ and $\mathrm{T}_{3}$ were transient and reversible in acute hepatic disease. Upon improvement of the liver function, serum $\mathrm{TSH}$ and $\mathrm{T}_{\mathbf{s}}$ also showed a tendency to normalize in accord with the reversible liver damage.

Another group of seven normal medical personnel and four patients with advanced but stable liver cirrhosis, and without clinical ascites, were included for the study to estimate the extrathyroidal $T_{4}$ conversion rate to $T_{3}$. Each subject was given $T_{4}, 0.25 \mathrm{mg} /$ day, by mouth starting 2 wk before the kinetic study to suppress the thyroidal secretion of $\mathrm{T}_{\mathbf{4}}$ and $\mathrm{T}_{\mathbf{8}} \mathrm{TSH}, \mathrm{T}_{\mathbf{4}}$, and $\mathrm{T}_{3}$ levels in these subjects were followed during the first 10 days. The mean serum TSH of the normal subjects was $4.8 \pm 2.4 \mu \mathrm{U} / \mathrm{ml}$ at the start and $4.5 \pm 2.4$ $\mu \mathrm{U} / \mathrm{ml}$ at the end of study. The serum $\mathrm{T}_{4}$ level in the normal subjects was $10.2 \pm 1.7 \mu \mathrm{g} / \mathrm{dl}$ at the start and $10.8 \pm 1.5 \mu \mathrm{g} / \mathrm{dl}$ at the end of study. The mean serum $\mathrm{T}_{3}$ rose from $122 \pm 23 \mathrm{ng} / \mathrm{dl}$ to $156 \pm 31 \mathrm{ng} / \mathrm{dl}$. Three of the seven normal subjects showed only a transient rise of serum $\mathrm{T}_{3}$ value, which returned to the original levels before the end of the study. The results obtained from 
the four hepatic patients are shown in Fig. 3. During T. replacement, the mean serum TSH level fell slightly in the four hepatic patients from $12.4 \pm 6.8$ to $9.4 \pm 5.1$ $\mu \mathrm{U} / \mathrm{ml}(P<0.01)$. The serum $\mathrm{T}_{4}$ level was unchanged, $7.0 \pm 1.6 \mu \mathrm{g} / \mathrm{dl}$ at the beginning and $8.5 \pm 1.7 \mu \mathrm{g} / \mathrm{dl}$ at the end of the study. The serum $T_{s}$ level was below normal in all of the hepatic patients at the start of the study. It failed to show any rise in three of the four patients during the study, although the average serum $\mathrm{T}_{3}$ level rose from $48 \pm 2$ to $62 \pm 32 \mathrm{ng} / \mathrm{dl}$. These findings showed that in the hepatic patients, supplement of $T_{4}$ substrate did not always normalize the serum $T_{\mathbf{z}}$ level. Therefore, failure of hypothalamus, pituitary, or thyroid cannot account for the reduced serum $T_{3}$ level in most of the hepatic patients.

Kinetic analysis of $T_{4}$ and $T_{3}$ in these seven normal subjects and four hepatic patients are tabulated in Table V. These normal subjects and hepatic patients did not show a significant difference in their disappearance rates, turnover rates, and volumes of distribution of either $T_{4}$ or $T_{3}$. The two groups also showed similar metabolic clearance rates. In the normal subjects, the $\mathrm{MCR}$ of $\mathrm{T}_{4}$ was $1.1 \pm 0.1$ liter/day (mean $\pm \mathrm{SD}$ ) and the MCR of $\mathrm{T}_{3}$ was $22.6 \pm 4.1$ liter/day. In the hepatic patients, the MCR of $T_{4}$ was $1.0 \pm 0.2$ liter/day and the MCR of $\mathrm{T}_{3}$ was $19.2 \pm 4.0$ liter/day. However, the

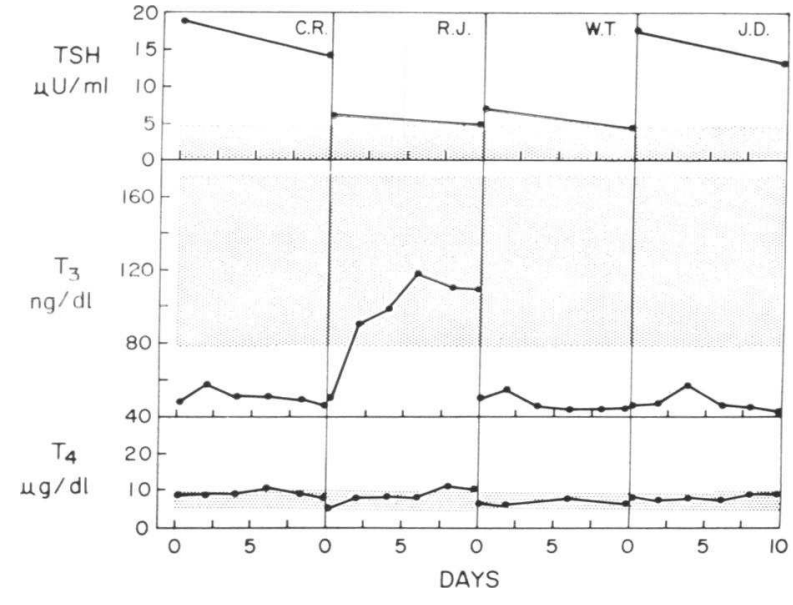

FIGURE 3 Four patients with advanced, but stable hepatic cirrhosis were given oral $T_{4}, 0.25 \mathrm{mg} /$ day. Serial serum samples were assayed for $\mathrm{TSH}, \mathrm{T}_{4}$, and $\mathrm{T}_{3}$ during the initial 10 days.

hepatic patients showed a definite failure to convert $T_{4}$ to $T_{s}$ as compared to the normal subjects. The seven normal subjects had a range of $\mathrm{T}_{4}$ to $\mathrm{T}_{3}$ conversion rates $31.4-40.2 \%$, with a mean of $35.7 \pm 6.4 \%$. The four hepatic patients had a range of $T_{4}$ to $T_{3}$ conversion

TABLE V

The Thyroxine Conversion Rate to Triiodothyronine in Normal Subjects and Hepatic Patients

\begin{tabular}{|c|c|c|c|c|c|c|c|}
\hline & \multicolumn{2}{|c|}{ Serum level } & \multicolumn{2}{|c|}{$\begin{array}{l}\text { Metabolic } \\
\text { clearance rate }\end{array}$} & \multicolumn{2}{|c|}{ Disposal rate } & \multirow{2}{*}{$\begin{array}{c}T_{4} \text { to } T_{3} \\
\text { conversion } \\
\text { rate }\end{array}$} \\
\hline & $T_{4}$ & $T_{3}$ & $T_{4}$ & $T_{3}$ & $T_{4}$ & $\mathrm{~T}_{3}$ & \\
\hline & \multicolumn{2}{|c|}{$\mu \mathrm{g} / \mathrm{liter}$} & \multicolumn{2}{|c|}{ liter/day } & \multicolumn{2}{|c|}{$\mu g / d a y$} & $\%$ \\
\hline \multicolumn{8}{|c|}{ Normal subjects } \\
\hline R. C. & 111 & 1.45 & 1.05 & 25.77 & 116 & 37 & 38.9 \\
\hline R. M. & 120 & 1.58 & 0.88 & 18.03 & 105 & 28 & 32.2 \\
\hline R. St. & 116 & 1.36 & 1.14 & 27.72 & 132 & 38 & 34.1 \\
\hline F. A. & 76 & 1.27 & 1.03 & 16.32 & 79 & 21 & 31.4 \\
\hline H. W. & 101 & 1.62 & 1.17 & 24.71 & 119 & 40 & 40.2 \\
\hline H. A. & 117 & 1.80 & 1.19 & 23.35 & 139 & 42 & 36.3 \\
\hline R. Sa. & 103 & 1.43 & 1.01 & 22.16 & 104 & 32 & 36.5 \\
\hline Mean & 106 & 1.50 & 1.07 & 22.58 & 114 & 34 & 35.7 \\
\hline$\pm \mathrm{SD}$ & 15 & 0.18 & 0.11 & 4.12 & 20 & 7 & 3.3 \\
\hline \multicolumn{8}{|c|}{ Liver patients } \\
\hline C. R. & 95 & 0.51 & 0.99 & 19.83 & 94 & 10 & 12.8 \\
\hline R. J. & 90 & 0.99 & 0.79 & 14.94 & 71 & 15 & 25.1 \\
\hline W. T. & 62 & 0.41 & 0.97 & 17.60 & 60 & 7 & 14.5 \\
\hline J. D. & 76 & 0.36 & 1.36 & 24.30 & 104 & 9 & 10.0 \\
\hline Mean & 81 & 0.57 & 1.03 & 19.17 & 82 & 10 & 15.6 \\
\hline$\pm \mathrm{SD}$ & 15 & 0.29 & 0.24 & 3.96 & 20 & 3 & 6.6 \\
\hline$P$ & 0.025 & 0.001 & NS & NS & 0.050 & $<0.001$ & $<0.001$ \\
\hline
\end{tabular}

All values were normalized to $70 \mathrm{~kg}$ body wt. 
rates $10.0-25.1 \%$, with a mean $15.6 \pm 6.6 \%(P<0.005)$. In the normal subjects the estimated disposal rates of $\mathrm{T}$. and $\mathrm{T}_{3}$ were $114 \pm 20 \mu \mathrm{g} / \mathrm{day}$ and $34 \pm 7 \mu \mathrm{g} / \mathrm{day}$, respectively, with a $T_{4}$ disposal to $T_{3}$ disposal ratio of 3.5. In the hepatic patients the disposal rate of $T_{4}$ was found to be low, $82 \pm 25 \mu \mathrm{g} /$ day, which suggests impairment of $T_{4}$ absorption in some of the patients. The $T_{4}$ tablets were given by the nursing staff to both groups, and the patients did not have other symptoms of malabsorption. The mean $\mathrm{T}_{3}$ disposal rate in the cirrhotic patients was reduced to $10 \pm 3 \mu \mathrm{g} /$ day with a $\mathrm{T}_{4}$ disposal/ $\mathrm{T}_{3}$ disposal of 8.2 , suggestive of a $70 \%$ decrease of $T_{3}$ production by $T_{4}$ deiodination. These findings suggest a significant impairment of peripheral $T_{4}$ conversion to $T_{3}$ in patients with advanced liver cirrhosis that leads to reduced serum $\mathrm{T}_{3}$ level.

\section{DISCUSSION}

The production of $T_{3}$ is now believed to come from both thyroidal secretion and peripheral thyroxine conversion (1-4). The maintenance of serum $T_{3}$ within its normal range is, therefore, a function of the concentration of serum $T_{3}$ binding proteins, the $T_{3}$ disposal rate, the thyroidal $T_{8}$ secretion rate, and the $T_{4}$ to $T_{3}$ conversion rate. Recently, several laboratories reported a significant reduction in the serum total $\mathrm{T}_{3}(21,22)$ and free $T_{s}$ levels (21) in the hepatic patients. The cause of these changes was believed to be failure of $T_{4}$ to convert to $T_{3}$. In the present study, four patients with advanced but stable liver cirrhosis were given $T_{4}$ by mouth, $0.25 \mathrm{mg} /$ day, for 10 days. Three of the four patients without other signs of malabsorption failed to elevate their serum $T_{8}$ value. Chopra and colleagues (21) also observed a normal $T_{s}$ rise in response to administration of thyrotropin-releasing hormone in patients with liver cirrhosis. Therefore, pituitary or thyroidal failure is not a likely etiology for the reduced serum $T_{3}$ level. This conclusion is supported by the measurement of the MCRs and the disposal rates of $T_{4}$ and $T_{3}$ and the $T_{4}$ to $T_{3}$ conversion rates with noncompartmental analysis in normal subjects and cirrhotic patients. The normal subjects had a $\mathrm{T}_{4}$ disposal/ $T_{a}$ disposal ratio of 3.5 , while the cirrhotic patients had a significant increase of $T_{4}$ disposal/ $T_{3}$ disposal ratio to 8.2. The mean $\mathrm{T}_{4}$ to $\mathrm{T}_{3}$ conversion rate was $34 \%$ for the normal subjects and $16 \%$ for the cirrhotic patients.

The kinetic data of normal subjects obtained from the present study showed a much larger fraction of the extrathyroidal $\mathrm{T}_{3}$ pool $(46 \pm 9 \%)$ derived from $\mathrm{T}_{4}$ conversion than that reported in our earlier study $(31 \%)$ (3). Due to methodologic difficulty in the competitive protein-binding assay of $T_{3}$, the serum $T_{3}$ level reported in our earlier study (3) was approximately twice our current serum $\mathrm{T}_{3}$ level for normal subjects, determined by radioimmunoassay. Radioimmunoassay of the same serum samples used in our earlier study (3) would modify our original conclusion and allow that approximately $62 \%$ of the total extrathyroidal pool of $\mathrm{T}_{3}$ or $82 \%$ of the daily $\mathrm{T}_{3}$ production was derived from $\mathrm{T}_{4}$ conversion in subjects with normal thyroid function. Similar estimates were reported by other investigators using radioimmunoassay for $T_{3}$ measurements $(4,5)$. Our present study employed a different experimental design and a different method of calculation from our earlier study (3). Yet the $\mathrm{T}_{4}$ to $\mathrm{T}_{3}$ conversion rate estimated by the present study was $36 \%$, similar to the estimate of $33 \%$ reported in our earlier study (3) and close to the estimate of $42 \%$ reported by Surks, Schadlow, Stock, and Oppenheimer (28). Such agreement between different methods and different laboratories lends support to the validity of our present method of calculation and to the conclusion of our present study, that the $T_{4}$ to $T_{3}$ conversion rate in the hepatic patients is reduced despite the fact that only a small number of liver patients were studied in the present report.

As compared to the average values of normal subjects, these cirrhotic patients had a $50 \%$ reduction in their mean $T_{4}$ to $T_{3}$ conversion rate and $70 \%$ reduction in their mean $T_{3}$ disposal rate. The kinetic study of hepatic patients reported by Inada and Sterling (18) did not include the kinetics of $T_{3}$. The present study agrees with their conclusion that the hepatic patients have essentially normal $T$, disappearance rates, but our estimation of the $T_{4}$ disposal rate was slightly lower than that of normal controls. In another kinetic study of the hepatic patients, McConnon, Row, and Volpe reported reduced $T_{4}$ production, normal serum total $T_{3}$ level, and elevated serum free $T_{3}$ level and $T_{3}$ production (29). These results are difficult to reconcile with the findings of other investigators $(18,21)$, as well as with our own observation (22), and underline the importance of proper staging and grouping of hepatic patients. McConnon and colleagues also used a competitive protein-binding technique now believed to overestimate serum $\mathrm{T}_{3}$ levels.

Alteration in serum proteins is one of the criteria commonly used in assessing the synthetic capacity in cirrhotic patients. In the serum of hepatic patients, the level of thyroxine-binding prealbumin was reported to be reduced $(18,20)$. The mean level of thyroxinebinding globulin was found to be normal, but there was wide variability of individual values. In the present study, the mean serum total $T_{4}$ was unchanged, but the mean values of both the serum free $T_{4}$ fraction and the actual serum free $T_{4}$ were elevated in the hepatic patients. At the same time, the mean serum 
total $T_{3}$ was reduced in the same group. The mean serum free $T_{3}$ fraction was elevated so that the actual serum free $T_{3}$ was low only in the patients with reduced serum total $T_{3}$, and it was elevated or normal in the patients who have normal values of serum total $T_{3}$. The resultant mean serum free $T_{8}$ of the hepatic patients was in the same range as that of the normal controls. The changes in the serum total and free $T_{3}$ were correlated with the severity of liver cirrhosis as reflected by the elevation of serum bilirubin and the reduction of serum albumin. Other investigators also reported elevated concentrations of serum free $T_{4}(18$, $21,29)$ associated with reduced concentrations of serum free $T_{\mathbf{3}}(21)$ in hepatic patients. These findings cannot be explained by alteration of binding proteins alone. Rather, they suggest augmented thyroidal secretion in response to reduced circulating $T_{3}$. The synthesis of $T_{4}$ is more active than the synthesis of $T_{3}$ in the thyroid (30). Therefore, the hepatic patients whose $T_{s}$ production is reduced due to impaired peripheral $T_{4}$ conversion to $T_{s}$, can compensate and maintain a normal serum concentration of $T_{4}$ more efficiently than a normal serum $T_{s}$ concentration.

Clinical signs of hypothyroidism develop after a prolonged period of thyroid hormone depletion. Our patients probably did not have $T_{8}$ depletion long enough to become myxedematous although many of them had biochemical hypothyroidism. In the two patients with acute alcoholic hepatitis, the serum $\mathrm{T}_{\mathbf{3}}$ and $\mathrm{TSH}$ levels appeared to parallel and normalize as the liver function improved. Also as a group, the hepatic patients showed a higher mean serum TSH level as compared to the normal controls. However, some of the hepatic patients did not show a significant rise of their serum $\mathrm{TSH}$ despite reduced serum total $T_{3}$ and free $T_{3}$. The level of serum $\mathrm{TSH}$ in these patients was not correlated with either serum free $T_{4}$, serum free $T_{3}$, or the ratio of the two. Nor was it correlated with the results of liver function tests. This puzzling finding is similar to the experience of Chopra and colleagues (21). Recently, reduced serum $T_{3}$ level was observed in patients with a wide variety of other illnesses (31-34) and caloric deprivation (35) in whom the serum $\mathrm{T}_{\mathbf{3}}$ level was low and the serum TSH level was in the normal range. The elevation of serum $\mathrm{TSH}$ value was reported only in patients with advanced liver disease $(21,22)$ or renal disease (34). Some of the patients with these disorders were found to have elevated serum free $T_{4}$ $(18,21,31,33)$ and tissue $T_{4}$ concentration (31). It is possible that $T_{3}$ is not the sole biologically active thyroid hormone. The presence of elevated serum and tissue $T_{4}$ concentrations is sufficient to keep the patients in an euthyroid state and the basal serum TSH level in the normal range. Most of these patients reported are said to be clinically euthyroid (21). Another postulate for the absence of any compensatory increase of serum $\mathrm{TSH}$ could be that a chronic state of $\mathrm{T}_{3}$ deficiency may alter the $T_{8}$ receptor in the pituitary. More work in this area is necessary to understand the TSH response in the hepatic patients as well as in the other low $T_{3}$ states.

Among the variety of illnesses associated with reduced serum $\mathrm{T}_{3}$ level are disorders of the cardiovascular and pulmonary systems, of liver and kidney, neoplasm, and caloric deprivation $(21,22,31,35)$. The relationship between $T_{3}$ metabolism and most of these disorders is not explained by our present knowledge. Not uncommonly, the liver patients also may have malnutrition and weight loss. However, a cause and effect relationship may be postulated between liver injury and abnormal $T_{4}$ and $T_{8}$ metabolism. In in vitro experimentation, perfused liver and liver tissue culture were shown to convert $T_{4}$ to $T_{3}(7,13)$. Reduced serum $T_{3}$ values $(21,22)$ were associated with liver cirrhosis and alcoholic hepatitis. The cellular damage of alcoholic hepatitis and cirrhosis was shown to be uniform and diffuse (36). In patients with advanced alcoholic cirrhosis, both the $T_{4}$ to $T_{3}$ conversion rate and the $T_{4}$ disposal/ $T_{3}$ disposal ratio were significantly reduced. Supplementary $T_{4}$ fed to these patients failed to normalize the serum $T_{3}$ level. To the extent as the acute liver injury from alcoholic hepatitis was reversible, the alterations in the serum level of $T_{8}$ was also reversible. Therefore, our findings are compatible with the postulate that liver may be a major site of the peripheral $T_{4}$ conversion to $T_{3}$ and extensive liver injury may significantly reduce $T_{4}$ conversion to $T_{3}$ and circulating $\mathrm{T}_{3}$ level.

\section{ACKNOWLEDGMENTS}

The authors wish to acknowledge the technical assistance of Ms. Candace Thurston and the secretarial assistance of Ms. Sharon McDaniel.

This research was supported in part by the Veterans Administration and by grants from the National Institutes of Health, AM-17332 and M01-RR-32.

\section{REFERENCES}

1. Braverman, L. E., S. H. Ingbar, and K. Sterling. 1970 Conversion of thyroxine $\left(T_{4}\right)$ to triiodothyronine $\left(T_{8}\right)$ in athyreotic human subjects. J. Clin. Invest. 49: 855864.

2. Sterling, K., M. A. Brenner, and E. S. Newman. 1970. Conversion of thyroxine to triiodothyronine in normal human subjects. Science (Wash. D. C.). 169: 10991100.

3. Pittman, C. S., J. B. Chambers, Jr., and V. H. Read. 1971. The extrathyroidal conversion rate of thyroxine to triiodothyronine in normal man. J. Clin. Invest. 50: $1187-1196$ 
4. Chopra, I. J., J. H. Dussault, D. A. Fisher, and D. H. Solomon. 1971. The sources of circulating triiodothyronine $\left(\mathrm{T}_{3}\right)$ in man. Clin. Res. 19: 560. (Abstr.)

5. Schwartz, H. L., M. I. Surks, and J. H. Oppenheimer. 1971. Quantitation of extrathyroidal conversion of Lthyroxine to $3,5,3^{\prime}$-triiodo-L-thyronine in the rat. $J$. Clin. Invest. 50: 1124-1130.

6. Fisher, D. A., I. J. Chopra, and J. H. Dussault. 1972. Extrathyroidal conversion of thyroxine to triiodothyronine in sheep. Endocrinology. 91: 1141-1144.

7. Becker, D. V., and J F Prudden 1959. The metabolism of $\mathrm{I}^{181}$-labeled thyroxine, triiodothyronine and diiodotyrosine by an isolated perfused rabbit liver. Endocrinology. 64: 136-148.

8. Rabinowitz, J. L., and E. S. Hercker. 1971. Thyroxine: conversion to triiodothyronine by isolated perfused rat heart. Science (Wash. D. C.). 173: 1242-1243.

9. Grinberg, R., E. M. Volpert, and S. C. Werner. 1963. In vivo deiodination of labeled $\mathrm{L}$-thyroxine to L-3, 5, 3'-triiodothyronine in mouse and human pituitaries. J. Clin. Endocrinol. Metab. 23: 140-142.

10. Albright, E. C., F. C. Larson, and R. H. Tust. 1954 In vitro conversion of thyroxine to triiodothyronine by kidney slices. Proc. Soc. Exp. Biol. Med. 86: 137-140.

11. Tata, J. R., J. E. Rall, and R. W. Rawson. 1957. Metabolism of L-thyroxine and L-3:5:3'-triiodothyronine by brain tissue preparations. Endocrinology. 60: 83-98.

12. Refetoff, S., R. Matalon, and M. Bigazzi. 1972. Metabolism of L-thyroxine $\left(T_{4}\right)$ and L-triiodothyronine $\left(T_{3}\right)$ by human fibroblasts in tissue culture: evidence for cellular binding proteins and conversion of $T_{4}$ to $T_{3}$ Endocrinology. 91: 934-947.

13. Sterling, K., M. A. Brenner, and V. F. Saldanha. 1973. Conversion of thyroxine to triiodothyronine by cultured human cells. Science (Wash. D. C.). 179: $1000-1001$.

14. Friis, T. 1958. Thyroxine metabolism in man estimated by means of $\mathrm{I}^{131}$-labelled L-thyroxine. Acta Endocrinol. 29: $587-601$

15. Vannotti, A., and T. Béraud. 1959. Functional relationships between the liver, the thyroxine-binding protein of serum, and the thyroid. J. Clin. Endocrinol. Metab. 19: 466-477.

16. Lennon, E. J., N. H. Engbring, and W. W. Engstrom. 1961. Studies of the rate of disappearance of labeled thyroxine from the intravascular compartment. J. Clin. Invest. 40: 996-1005.

17. Cavalieri, R. R., and G. L. Searle. 1966. The kinetics of distribution between plasma and liver of ${ }^{111} \mathrm{I}$-labeled L-thyroxine in man: observations of subjects with normal and decreased serum thyroxine-binding globulin. J. Clin. Invest. 45: 939-949.

18. Inada, M., and K. Sterling. 1967. Thyroxine turnover and transport in Laennec's cirrhosis of the liver. J. Clin. Invest. 46: 1275-1282.

19. Oppenheimer, J. H., G. Bernstein. and M. I. Surks. 1968. Increased thyroxine turnover and thyroidal function after stimulation of hepatocellular binding of thyroxine by phenobarbital. J. Clin. Invest. 47: 1399-1406.

20. Bernsterin, G., S. A. Artz, J. Hasen, and J. H. Oppenheimer. 1968. Hepatic accumulation of ${ }^{125} \mathrm{I}$-thyroxine in the rat: augmentation by phenobarbital and chlordane. Endocrinology. 82: 406-409.

21. Chopra, I. J., D. H. Solomon, U. Chopra, R. T. Young, and J. N. Chua Teco. 1974. Alterations in circulating thyroid hormones and thyrotropin in hepatic cirrhosis: evidence for euthyroidism despite subnormal serum triiodothyronine. J. Clin. Endocrinol. 39: 501-511.

22. Nomura, S., J. B. Chambers, Jr., M. W. Buck, C. C. Thurston, and C. S. Pittman. 1974. The peripheral conversion of thyroxine $\left(T_{4}\right)$ to triiodothyronine $\left(T_{3}\right)$ in liver patients. Clin. Res. 22: 62A. (Abstr.)

23. Raud, H. R., and D. Odell. 1969. Radioimmunoassay of human thyrotrophin. Br. J. Hosp. Med. 2: 13661376.

24. Chopra, I. J. 1972. A radioimmunoassay for measurement of thyroxine in unextracted serum. J. Clin. Endocrinol. Metab. 34: 938-947.

25. Chopra, I. J., D. H. Solomon, and G. N. Beall. 1971. Radioimmunoassay for measurement of triiodothyronine in human serum. J. Clin. Invest. 50: 2033-2041.

26. Sterling, K., and M. A. Brenner. 1966. Free thyroxine in human serum: simplified measurement with the aid of magnesium precipitation. J. Clin. Invest. 45: 153-163.

27. Tait, J. F. 1963. Review: the use of isotopic steroids for the measurement of production rates in vivo. J. Clin. Endocrinol. Metab. 23: 1285-1297.

28. Surks, M. I., A. R. Schadlow, J. M. Stock, and J. H. Oppenheimer. 1973. Determination of iodothyronine absorption and conversion of L-thyroxine $\left(\mathrm{T}_{4}\right)$ to L-triiodothyronine $\left(\mathrm{T}_{3}\right)$ using turnover rate techniques. J. Clin. Invest. 52: 805-811.

29. McConnon, J., V. V. Row, and R. Volpé. 1972. The influence of liver damage in man on the distribution and disposal rates of thyroxine and triiodothyronine. $J$. Clin. Endocrinol. Metab. 34: 144-151.

30. Chopra, I. J., D. A. Fisher, D. H. Solomon, and G. N. Beall. 1973. Thyroxine and triiodothyronine in the human thyroid. J. Clin. Endocrinol. Metab. 36: 311-316.

31. Sullivan, P. R. C., J. A. Bollinger, and S. Reichlin. 1973. Selective deficiency of tissue triiodothyronine: a proposed mechanism of elevated free thyroxine in the euthyroid sick. J. Clin. Invest. 52: 83a. (Abstr.)

32. Carter, J. N., C. J. Eastman, J. M. Corcoran, and L. Lazarus. 1974. Effect of severe, chronic illness on thyroid function. Lancet. 2: 971-974.

33. Bermudez, F. J., M. I. Surks, and J. H. Oppenheimer. 1974. High incidence of decreased plasma triiodothyronine $\left(\mathrm{T}_{3}\right)$ concentration in a variety of nonthyroidal disease. Program of the 50th Annual Meeting of American Thyroid Association, St. Louis, Mo. T15.

34. Fang, V. S., V. S. Lim, and S. Refetoff. 1974. Triiodothyronine $\left(T_{3}\right)$ hypothyroidism in patients with renal insufficiency. Program of the 50th Annual Meeting of American Thyroid Association, St. Louis, Mo. T16.

35. Portnay, G. I., J. T. O'Brian, J. Bush, A. G. Vagenakis, F. Azizi, R. A. Arky, S. H. Ingbar, and L. E. Braverman. 1974. The effect of starvation on the concentration and binding of thyroxine and triiodothyronine in serum and on the response of TRH. J. Clin. Endocrinol. Metab. 39 : 191-194.

36. Lieber, C. S. 1973. Liver adaptation and injury in alcoholism. N. Engl. J. Med. 288: 356-362. 